\title{
SEBASTIAN KOWALSKI
}

ORCID: 0000-0003-1993-1211

Uniwersytet Zielonogórski

\section{ODPOWIEDZIALNOŚĆ KARNA KOMORNIKA SĄDOWEGO ZA ZŁOŻENIE FAŁSZYWEGO OŚWIADCZENIA MAJĄTKOWEGO}

\begin{abstract}
Abstrakt: Celem opracowania jest przybliżenie zagadnienia odpowiedzialności karnej komornika sądowego za złożenie fałszywego oświadczenia majątkowego. $Z$ jednej strony autor omawia ustawowe znamiona czynu zabronionego z art. $233 \S 6$ k.k. w perspektywie zachowania polegającego na złożeniu nieprawdziwego w swej treści oświadczenia majątkowego, z drugiej zaś przedstawia karnoprawne następstwa przypisania wymienionego przestępstwa. W ocenie autora obowiązujące rozwiązania legislacyjne dotyczące odpowiedzialności karnej komornika sądowego za złożenie fałszywego oświadczenia majątkowego są nadmiernie represyjne. W szczególności są one — w zakresie sankcji — dalej idące niż następstwa złożenia fałszywego oświadczenia majątkowego przez premiera, ministra, czy wiceministra. De lege ferenda autor postuluje przede wszystkim ujednolicenie odpowiedzialności karnej funkcjonariuszy publicznych za podanie nieprawdziwych danych w oświadczeniu majątkowym.
\end{abstract}

Słowa kluczowe: przestępstwo, kara, fałszywe oświadczenie majątkowe, komornik sądowy

Komornik sądowy jest jednym z wielu funkcjonariuszy publicznych zobowiązanych do corocznego składania oświadczenia o stanie majątku zawierającego informacje określone w urzędowym formularzu oświadczenia majątkowego. Z chwilą wejścia w życie ustawy z dnia 22 marca 2018 roku o komornikach sądowych ${ }^{1}$ złożenie fałszywego oświadczenia majątkowego przez komornika sądowego stało się czynem zabronionym, zagrożonym odpowiedzialnością karną. Chodzi tu o odpowiedzialność karną za przestępstwo z art. 233 § 6 k.k. w zw. z art. 233 § 1 kodeksu karnego ${ }^{2}$ - przestępstwo umyślne, ścigane z oskarżenia publicznego. Ani nowa

1 Tekst jedn. Dz.U. z 2020 r. poz. 121 ze zm.; dalej: u.k.s. lub ustawa o komornikach sądowych.

2 Tak kwalifikuje się przestępstwo złożenia fałszywego oświadczenia majątkowego, w szczególności z uwagi na odwołanie zawarte w $§ 6$ do treści § 1 wymienionego artykułu. W dalszej części opracowania będę jednak używał kwalifikacji: art. $233 \S 6$ k.k. Z jednej strony czynić to będzie tekst bardziej przejrzystym, z drugiej zaś — w przypadku oświadczeń majątkowych odniesienie się do znamienia strony przedmiotowej z art. $233 \S 1$ k.k., polegającego na złożeniu oświadczenia mają- 
regulacja treści oświadczenia majątkowego komornika sądowego, ani skutki złożenia przez niego oświadczenia majątkowego zawierającego nieprawdziwą treść, nie zostały dotąd poddane gruntownej analizie w piśmiennictwie ${ }^{3}$. Natomiast w uzasadnieniu projektu ustawy o komornikach sądowych kwestię odpowiedzialności karnej komornika sądowego za złożenie fałszywego oświadczenia majątkowego pominięto milczeniem ${ }^{4}$. Tymczasem doświadczenia spraw karnych, na przykład pracowników organów samorządowych oskarżanych o składanie nieprawdziwych oświadczeń majątkowych, wskazują, że sprawy tego rodzaju są trudne i czasochłonne, co z uwagi chociażby na skutki postawienia komornikowi zarzutu popełnienia przestępstwa ma — rzecz jasna — ogromne znaczenie ${ }^{5}$.

Celem tego opracowania jest przybliżenie zagadnienia odpowiedzialności karnej komornika sądowego za złożenie fałszywego oświadczenia majątkowego, a zatem $\mathrm{z}$ jednej strony omówienie ustawowych znamion czynu zabronionego $\mathrm{z}$ art. $233 \S 6 \mathrm{k} . \mathrm{k}$. w perspektywie zachowania polegającego na złożeniu nieprawdziwego w swej treści oświadczenia majątkowego, z drugiej zaś — przedstawienie karnoprawnych następstw przypisania wymienionego przestępstwa. Niezależnie od tego, z uwagi na kontrowersyjne — w mojej ocenie nadmiernie represyjne - uregulowanie odpowiedzialności karnej komornika sądowego za złożenie fałszywego oświadczenia majątkowego, przedstawione zostały również postulaty de lege ferenda, wyraźnie artykułowane w konkluzjach.

\section{ZŁOŻENIE FAŁSZYWEGO OŚWIADCZENIA MAJĄTKOWEGO JAKO PRZESTĘPSTWO}

W kodeksie karnym nie typizuje się przestępstwa fałszywego złożenia oświadczenia majątkowego komornika sądowego ani przestępstwa złożenia oświadczenia majątkowego jako takiego. Natomiast w art. $233 \S 6$ k.k. typizuje się przestępstwo złożenia fałszywego oświadczenia zagrożonego taką samą karą, jak przestępstwo złożenia nieprawdziwych zeznań — aktualnie karą pozbawienia wolności od sześciu miesięcy do ośmiu lat. Pod rygorem odpowiedzialności karnej za

cego służyć za dowód w postępowaniu sądowym lub innym prowadzonym na podstawie ustawy, jest akurat niemożliwe, oświadczenia majątkowego nie składa się bowiem w żadnym postępowaniu (o tym dalej).

3 Aczkolwiek w piśmiennictwie poddawano analizie odpowiedzialność karną za złożenie ogólnie rzecz ujmując - fałszywego oświadczenia majątkowego przez innych funkcjonariuszy publicznych. Zob. zwłaszcza M. Jachimowicz, Odpowiedzialność karna za naruszenie przepisów ustawy ,antykorupcyjnej”, „Prokuratura i Prawo” 2006, nr 10, passim; M. Sławiński, Znamiona przedmiotowe i podmiotowe przepisów penalizujących złożenie fałszywego oświadczenia majątkowego przez osobe petniaca funkcje publiczna (wyktadnia art. 233 \& 6 k.k. w zw. z art. 233 \& 1 k.k. oraz art. 14 ustawy antykorupcyjnej), „Czasopismo Prawa Karnego i Nauk Penalnych” 2015, z. 4, passim.

${ }^{4}$ Uzasadnienie projektu ustawy o komornikach sądowych, druk nr 1582 Sejmu RP VIII Kadencji.

5 Zob. art. 18 ust. 1 pkt 1 u.k.s. i art. 20 ust. 1 pkt 4 u.k.s. 
to przestępstwo komornik sądowy składa oświadczenie majątkowe (art. 32 ust. 3 u.k.s.). Warto dodać, że podobnie uregulowano odpowiedzialność karną za złożenie fałszywego oświadczenia majątkowego między innymi posłów i senatorów ${ }^{6}$, sędziego ${ }^{7}$ czy niektórych funkcjonariuszy publicznych zatrudnionych $\mathrm{w}$ jednostkach samorządu terytorialnego ${ }^{8}$.

Inaczej uregulowana jest zaś odpowiedzialność karna za złożenie fałszywego oświadczenia przez osoby zajmujące kierownicze stanowiska państwowe w rozumieniu przepisów o wynagrodzeniu osób zajmujących kierownicze stanowiska państwowe oraz przez funkcjonariuszy Straży Granicznej ${ }^{9}$. Zarówno w ustawie antykorupcyjnej, jak i w ustawie o Straży Granicznej, stypizowano przestępstwo podania nieprawdy w oświadczeniu (majątkowym) zagrożone karą pozbawienia wolności do lat pięciu, a zarazem typ uprzywilejowany tego czynu zabronionego — wypadek mniejszej wagi ${ }^{10}$.

Określone w art. $233 \S 6$ k.k. przestępstwo złożenia fałszywego oświadczenia znajduje się w rozdziale XXX zatytułowanym „Przestępstwa przeciwko wymiarowi sprawiedliwości”. Nie miało ono odpowiednika w poprzednim k.k.. Niedługo po wejściu w życie aktualnie obowiązującego komentatorzy krótko zwracali uwagę, że wymienionym przepisem ustawodawca rozszerzył odpowiedzialność za składanie fałszywych zeznań, opinii i tłumaczeń na składanie fałszywych oświadczeń ${ }^{11}$.

Warto zauważyć, że przestępstwo złożenia fałszywego oświadczenia uregulowane jest w ostatnim przepisie art. 233 k.k., który typizuje przede wszystkim przestępstwo złożenia nieprawdziwych zeznań. Warunkiem odpowiedzialności

6 Art. 35, ust. 1 i 9 ustawy z dnia 9 maja 1996 roku o wykonywaniu mandatu posła i senatora (tekst jedn. Dz.U. z 2018 r. poz. 1799 ze zm.).

7 Art. 87 § 1 i $\S 9$ ustawy z dnia 27 lipca 2001 roku — Prawo o ustroju sądów powszechnych (tekst jedn. Dz.U. z 2019 r. poz. 52 ze zm.).

8 Art. 24h i 241 ustawy z dnia 8 marca 1990 roku o samorządzie gminnym (tekst jedn. Dz.U. z 2020 r. poz. 713 ze zm.), art. 25c i 25 g ustawy z dnia 5 czerwca 1998 roku o samorządzie powiatowym (tekst jedn. Dz.U. z 2020 r. poz. 920 ze zm.), art. 27c ustawy z dnia 5 czerwca 1998 roku o samorządzie województwa (tekst jedn. Dz.U. z 2020 r. poz. 1668 ze zm.).

9 Zob. art. 10 i art. 14 ustawy z dnia 21 sierpnia 1997 roku o ograniczeniu prowadzenia działalności gospodarczej przez osoby pełniące funkcje publiczne (tekst jedn. Dz.U. z 2019 r. poz. 2399 ze zm.); dalej: ustawa antykorupcyjna oraz art. 91a i art. 147b ustawy z dnia 12 października 1990 roku o Straży Granicznej (tekst jedn. Dz.U. z 2020 r. poz. 305 ze zm.); dalej: u.s.g. Szerzej na temat podstaw prawnych odpowiedzialności za złożenie nieprawdziwego oświadczenia majątkowego zob. Centralne Biuro Antykorupcyjne, Oświadczenia majątkowe (wydanie uzupetnione), „Przegląd Antykorupcyjny" 2019, nr 1, s. 54-57 i 72-73.

10 Art. 14 ustawy antykorupcyjnej, art. 147b u.s.g. Podkreślić tu jednak należy, że przestępstwo stypizowane $\mathrm{w}$ art. 14 ustawy antykorupcyjnej dotyczy podania nieprawdy nie tylko w oświadczeniu majątkowym. Godzi się zaznaczyć, że w piśmiennictwie nie zawsze traktuje się wypadek mniejszej wagi jako typ uprzywilejowany przestępstwa.

11 Zob. na przykład O. Górniok, [w:] Kodeks karny. Komentarz, t. III. Art. 117-363, red. O. Górniok, S. Hoc, S. M. Przyjemski, Gdańsk 1999, s. 263; Z. Kallaus, Przestępstwa przeciwko wiarygodności dokumentów, „Nowa kodyfikacja karna. Kodeks karny. Krótkie komentarze” 1998, z. 7, s. 107-108. 
karnej za fałszywe oświadczenie jest — podobnie jak w odniesieniu do odpowiedzialności za złożenie nieprawdziwego zeznania - uprzedzenie składającego oświadczenie o odpowiedzialności karnej za fałszywe oświadczenie. Istotnie, formularz oświadczenia majątkowego komornika sądowego zawiera, usytuowane bezpośrednio nad podpisem składanym na końcu całego dokumentu, uprzedzenie o treści ujętej pogrubionym drukiem: „Jestem świadomy(a) odpowiedzialności karnej za złożenie fałszywego oświadczenia" 12 .

W doktrynie i orzecznictwie przyjmuje się, że rodzajowym przedmiotem ochrony w rozdziale XXX k.k. jest prawidłowe funkcjonowanie administracji publicznej in genere, zaś w odniesieniu do przepisów art. 233 k.k. chodzi o zapewnienie wiarygodności ustaleń dokonywanych w postępowaniu sądowym lub $\mathrm{w}$ innym postępowaniu prowadzonym na podstawie ustawy ${ }^{13}$. Dlatego $\mathrm{w}$ postępowaniu karnym w sprawie o przestępstwo z art. $233 \S 6$ k.k. nie ma pokrzywdzonego $^{14}$. Jednakże składający oświadczenie majątkowe komornik sądowy nie bierze udziału w żadnym postępowaniu prowadzonym na podstawie ustawy — ani sądowym, ani innym - lecz wykonuje obowiązek nałożony na niego, jako funkcjonariusza publicznego, w przepisach art. 32 ust. 1 i 2 u.k.s. Dlatego też nie sposób w odniesieniu do kryminalizacji złożenia fałszywego oświadczenia majątkowego komornika sądowego bronić poglądu, że dobrem bezpośrednio chronionym jest w tym wypadku prawdziwość ustaleń jakiegokolwiek postępowania ${ }^{15}$. W wypad-

12 Załącznik do rozporządzenia Ministra Sprawiedliwości z dnia 18 grudnia 2018 roku w sprawie wzoru formularza oświadczenia o stanie majątkowym składanego przez komorników sądowych (Dz.U. z 2018 r. poz. 2444), s. 5. W myśl art. 32 ust. 3 u.k.s. komornik sądowy składający oświadczenie jest obowiązany do zawarcia w nim klauzuli o następującej treści: „Jestem świadomy odpowiedzialności karnej za złożenie fałszywego oświadczenia”. Klauzula ta zastępuje pouczenie organu uprawnionego do odebrania oświadczenia o odpowiedzialności karnej za złożenie fałszywego oświadczenia.

13 Zob. na przykład uchwałę Sądu Najwyższego z 22 stycznia 2003 roku, I KZP 39/02, OSNKW 2003, z. 1-2, poz. 1; Z. Młynarczyk, Fatszywe zeznania w polskim prawie karnym, Warszawa 1971, s. 77; M. Kulik, Czy bezpodstawne uchylenie się od złożenia zeznania jest zatajeniem prawdy w rozumieniu art. 233 \& 1 k.k.?, „Wojskowy Przegląd Prawniczy” 2003, nr 3, s. 44; W. Zalewski, [w:] Kodeks karny. Część szczególna, t. 2. Komentarz do art. 222-316, red. M. Królikowski, R. Zawłocki, Warszawa 2017, komentarz do art. 233, nb II. 1.

14 Por. postanowienie Sądu Najwyższego z 25 marca 2010 roku, IV KK 316/09, Legalis nr 240719.

15 Naturalnie dotyczy to także innych funkcjonariuszy publicznych składających oświadczenia majątkowe pod rygorem odpowiedzialności karnej z art. $233 \S 6$ k.k. W praktyce zagadnienie to doskonale oddaje sprawa byłego ministra, w toku której został skazany za złożenie fałszywego oświadczenia majątkowego w związku z nieujawnieniem w nim faktu posiadania drogiego zegarka, w której to sprawie chodziło wszakże o zegarek, którego posiadania nie ukrywał, a nieujawnienie tegoż $\mathrm{w}$ oświadczeniu nie wiązało się z jakimkolwiek postępowaniem prowadzonym na podstawie ustawy, ale „dociekliwością” autora tekstów w jednej z gazet; zob. wyrok Sądu Rejonowego dla Warszawy-Śródmieścia w Warszawie z 27 listopada 2014 roku, II K 119/14, http://orzeczenia. srodmiescie.warszawa.so.gov.pl/content/\$N/154505300001006_II_K_000119_2014_Uz_201501-19_001 (dostęp: 15.11.2020). Por. B. Kunicka-Michalska, [w:] Kodeks karny. Komentarz, red.

A. Wąsek, Warszawa 2010, komentarz do art. 233, nb II. 
ku penalizacji oświadczeń majątkowych komorników sądowych ustawodawca chroni dobro, jakim jest prawdziwość informacji o ich stanie majątku ujawnianych w ramach tego oświadczenia. Ochrona zgodności tych oświadczeń z prawdą ma na celu ułatwienie odpowiednim służbom państwowym przeciwdziałania korupcji oraz zapobiegania gospodarowaniu przez komorników sądowych majątkiem w sposób niezgodny z prawem czy zasadami etyki zawodowej, na przykład poprzez uzyskiwanie dodatkowych dochodów z wątpliwych etycznie źródeł lub zaciąganie nader wysokich zobowiązan ${ }^{16}$. Fałsz w oświadczeniu majątkowym może rodzić tylko podejrzenie wystąpienia korupcji lub innych niepożądanych, a wręcz patologicznych praktyk dotyczących gospodarowania majątkiem, nie wskazuje zaś wprost na tego rodzaju zjawiska; niekoniecznie każdy przypadek złożenia fałszywego oświadczenia majątkowego musi pociągać za sobą wystąpienie zjawisk korupcyjnych ${ }^{17}$.

\section{USTAWOWE ZNAMIONA STRONY PRZEDMIOTOWEJ CZYNU ZABRONIONEGO Z ART. $233 \S 6$ K.K.}

Przestępstwo złożenia fałszywego oświadczenia, stypizowane w art. $233 \S 6$ k.k., może być popełnione wyłącznie przez osobę składającą oświadczenie, co do którego ustawa przewiduje ów rygor odpowiedzialności karnej. Takim oświadczeniem jest oświadczenie majątkowe komornika sądowego, o którym mowa w art. 32 ust. 1 u.k.s. Komornik sądowy ma obowiązek złożyć oświadczenie prezesowi właściwego sądu apelacyjnego w dwóch egzemplarzach. Składa się je przed objęciem stanowiska komornika, a następnie co roku, do dnia 30 kwietnia, według stanu na dzień 31 grudnia roku poprzedniego, a także w terminie 30 dni od dnia zwolnienia ze stanowiska komornika.

Odpowiedzialności karnej podlega komornik sądowy, który składa dane oświadczenie, a więc przestępstwo z art. $233 \S 6$ k.k. może być popełnione tylko przez działanie - $\mathrm{z}$ chwilą przedstawienia oświadczenia prezesowi właściwego sądu apelacyjnego. Zaniechanie złożenia oświadczenia majątkowego w ustawowo

16 Por. Centralne Biuro Antykorupcyjne, op. cit., s. 53; R. Reiwer, Ustawa o komornikach sądowych. Komentarz, Warszawa 2019, komentarz do art. 32, nb 3. Zob. też D. Gruszecka et al., Działalność gospodarcza, ograniczenie dla osób petniących funkcje publiczne. Art. 14, [w:] System prawa karnego, t. 11. Szczególne dziedziny prawa karnego. Prawo wojskowe, skarbowe i pozakodeksowe, red. M. Bojarski, Warszawa 2018, s. 715. Szerzej na temat ratio legis instytucji oświadczenia majątkowego zob. M. Sławiński, Penalizacja złożenia fałszywego oświadczenia majątkowego przez osobę pelniąca funkcję publiczna. Wybrane aspekty dotyczace bezprawności, systematyki przepisów oraz dobra prawnie chronionego, „Czasopismo Prawa Karnego i Nauk Penalnych” 2015, z. 1, s. 104 i piśmiennictwo cytowane przez tego autora w przypisie 11.

17 M. Sławiński, Penalizacja..., s. 125. 
wymaganym terminie nie podlega kwalifikacji z art. $233 \S 6$ k.k. ${ }^{18}$ Funkcjonariusz publiczny, który wbrew obowiązkowi w ogóle nie składa oświadczenia majątkowego, nie wprowadza nikogo w błąd co do stanu swego majątku ani nie ujawnia zafałszowanego obrazu tegoż. Dlatego zachowanie komornika sądowego, który nie składa wymaganego oświadczenia majątkowego, należałoby ewentualnie poddawać ocenie karnoprawnej z perspektywy art. $231 \S 1$ k.k.

Ustawodawca wskazuje jako znamię czynu zabronionego złożenie fałszywego oświadczenia, a więc niewątpliwie oświadczenia majątkowego niezgodnego z prawdą. Wymaganą od komornika sądowego treść oświadczenia majątkowego wyznaczają przepisy art. 32 ust. 1 i 2 u.k.s., przy czym oświadczenie majątkowe składane jest na formularzu zgodnie z wzorem opracowanym przez Ministra Sprawiedliwości ${ }^{19}$. Komornik sądowy ma obowiązek zawrzeć w oświadczeniu majątkowym informacje o: 1. posiadanych zasobach pieniężnych; 2. posiadanych nieruchomościach i tytułach prawnych do ich posiadania; 3. posiadanych rzeczach ruchomych o wartości jednostkowej powyżej 10000 złotych; 4. posiadanych udziałach i akcjach w spółkach prawa handlowego; 5. posiadanych instrumentach finansowych w rozumieniu ustawy z dnia 29 lipca 2005 roku o obrocie instrumentami finansowymi ${ }^{20} ; 6$. dochodach podlegających opodatkowaniu podatkiem dochodowym od osób fizycznych, uzyskanych w okresie roku przed dniem, na który składane jest oświadczenie, o ile ich łączna wartość przekracza 10000 złotych, i ich źródłach; 7. nabytym przez składającego oświadczenie albo jego małżonka od Skarbu Państwa, innej państwowej osoby prawnej, jednostek samorządu terytorialnego, ich związków lub samorządowej osoby prawnej, mieniu, które podlegało zbyciu w drodze przetargu; oraz 8 . wierzytelnościach i zobowiązaniach pieniężnych o wartości powyżej 10000 złotych. Wzór oświadczenia majątkowego określony przez Ministra Sprawiedliwości powinien w założeniu uszczegóławiać zakres danych wymaganych w oświadczeniu majątkowym komornika sądowego. Tymczasem w piśmiennictwie niejednokrotnie podkreślano, że nie tylko urzędowo określony wzór oświadczenia majątkowego komornika sądowego, ale i jemu podobne, dotyczące innych funkcjonariuszy publicznych, są nieczytelne, rodzą zbyt wiele kontrowersji i wymagają za daleko idących zmian, aby uczciwa osoba nie miała żadnych wątpliwości interpretacyjnych bądź obaw, że nie wpisała jakiegoś składnika majątku poprzez niecelowe pominięcie ${ }^{21}$.

18 Por. uchwałę Sądu Najwyższego z 22 stycznia 2003 roku, I KZP 39/02, OSNKW 2003, nr 1-2, poz. 1 .

19 Zob. rozporządzenie Ministra Sprawiedliwości z dnia 18 grudnia 2018 roku w sprawie wzoru formularza oświadczenia o stanie majątkowym składanego przez komorników sądowych (Dz.U. z 2018 r. poz. 2444).

20 Dz.U. z 2018 r. poz. 2286 ze zm.

${ }^{21}$ Centralne Biuro Antykorupcyjne, op. cit., s. 77. Zob. też S. Kowalski, Oświadczenie majątkowe komornika sądowego-zagadnienie wtaściwego określenia wzoru formularza, „Przegląd Prawa Egzekucyjnego" 2020, nr 8, s. 70-86. 
W fałszywym oświadczeniu majątkowym zawarte są informacje niezgodne z prawdą, a więc: 1. nie zawiera ono wszystkich danych, które powinny znaleźć się w oświadczeniu majątkowym (na przykład nie wymieniono wszystkich posiadanych przez składającego oświadczenie rzeczy ruchomych o wartości przekraczającej $10000 \mathrm{zl);} \mathrm{lub} \mathrm{2.} \mathrm{zawiera} \mathrm{wymagane} \mathrm{dane,} \mathrm{ale} \mathrm{są} \mathrm{one} \mathrm{nieprawdziwe}$ (na przykład zaniżono wielkość powierzchni działki posiadanej przez składającego oświadczenie). Takie oświadczenie uniemożliwia rzetelne ustalenie majątku komornika sądowego w wymaganym ustawowo zakresie. W praktyce ustalenie zgodności oświadczenia majątkowego z prawdą wymaga skonfrontowania z sobą informacji, których ujęcia w tym oświadczeniu wymagają obowiązujące przepisy, z tymi, które rzeczywiście zostały w nim zawarte. Jeżeli konfrontacja ta wykaże braki w złożonym oświadczeniu, to możliwe, że jest ono fałszywe, jednak nie zawsze musi tak być. Ujawnione braki mogły wyniknąć z nieprawidłowego wypełnienia oświadczenia majątkowego, które mimo to pozwala ustalić stan majątku składającego oświadczenie w zakresie wymaganym przepisami art. 32 ust. 1 i 2 u.k.s. Przykładowo ujawnienie przez komornika sądowego w oświadczeniu majątkowym zawarcia umowy leasingowej służącej sfinansowaniu uzyskania samochodu terenowego marki J. o wartości 180000 zł, przy jednoczesnym zaniechaniu ujawnienia posiadania tegoż samochodu w części III oświadczenia majątkowego, wskazuje jedynie na nieprawidłowe wypełnienie danego oświadczenia, ale nie prowadzi do wniosku, że oświadczenie jest niezgodne z prawdą. Nie wydaje się bowiem, aby zasadne było uznanie za niezgodne z prawdą oświadczenia majątkowego, na podstawie treści którego można uzyskać wszystkie wymagane informacje dotyczące majątku osoby składającej to oświadczenie, zaś z takiego zapisu należy domniemywać, że składający oświadczenie posiada samochód J. wartości 180000 zł, co do którego zaciągnął zobowiązanie na podstawie umowy leasingowej.

Przepisy ustawy o komornikach sądowych milczą na temat możliwości złożenia korekty oświadczenia majątkowego, a więc dokumentu, w którym komornik sądowy - poprawiając wcześniejsze, nieprawdziwe w swej treści, oświadczenie — prawdziwie podaje wymagane od niego informacje. Skorygowanie złożonego oświadczenia majątkowego może być następstwem ujawnienia pomyłki, niezrozumienia treści wzoru formularza, zapomnienia. Jakkolwiek ustawodawca nie kreuje instytucji korekty oświadczenia majątkowego, to jednak w moim przekonaniu nie ma powodów, aby odmawiać dopuszczenia możliwości złożenia tejże. In concreto może to mieć nader istotne znaczenie w ewentualnym postępowaniu karnym prowadzonym w związku z ujawnieniem nieprawdziwego oświadczenia majątkowego, dowodząc braku zamiaru po stronie składającego oświadczenie, który wszak 
dobrowolnie ujawnia nieprawdziwość treści poprzednio złożonego oświadczenia ${ }^{22}$. Warto podkreślić, że takie znaczenie złożonej korekty przyjęto w orzecznictwie ${ }^{23}$.

Przypisanie popełnienia przestępstwa $\mathrm{z}$ art. $233 \S 6$ k.k. jest niezależne od wystąpienia jakiegokolwiek skutku ${ }^{24}$. Komornik składający fałszywe oświadczenie majątkowe może zatem ponieść odpowiedzialność karną bez względu na to, czy w następstwie złożenia takiego oświadczenia doszło do zatajenia ważkich informacji skutkujących dla innego podmiotu szkodą tudzież utrudnienia jakiegoś postępowania prowadzonego na podstawie ustawy itp.

\section{USTAWOWE ZNAMIONA STRONY PODMIOTOWEJ CZYNU ZABRONIONEGO Z ART. 233 § 6 K.K.}

Przestępstwo złożenia fałszywego oświadczenia jest przestępstwem umyślnym. Mając na względzie powszechne znaczenie sformułowania „dawać fałszywe świadectwo" 25 tudzież przymiotnika „fałszywy”26, można powątpiewać, czy przestępstwo to może być popełnione z zamiarem ewentualnym ${ }^{27}$. Jednakże w doktrynie wyraźnie przeważa przekonanie, że wymienione przestępstwo może być popełnione zarówno w zamiarze bezpośrednim, jak i ewentualnym² ${ }^{28}$.

22 Zachowanie osoby podejrzewanej o popełnienie przestępstwa następujące po zachowaniu mogącym wyczerpywać ustawowe znamiona czynu zabronionego może mieć szczególne znaczenie dla oceny, czy dana osoba działała umyślnie czy nieumyślnie.

23 Wyrok Sądu Okręgowego w Sieradzu z 1 października 2014 roku, II Ka 223/14, niepubl. W sprawie, w której zapadło to rozstrzygnięcie, ustalenie, że oskarżona złożyła korektę oświadczenia, było ważnym argumentem przemawiającym za warunkowym umorzeniem postępowania karnego.

${ }^{24}$ Inaczej zob. A. Wojtaszczyk, W. Wróbel, W. Zontek, Przestępstwa przeciwko wymiarowi sprawiedliwości, [w:] System prawa karnego, t. 8. Przestępstwa przeciwko państwu i dobrom zbiorowym, red. L. Gardocki, Warszawa 2018, s. 692-693. Jest to jednak w dużej mierze kwestia określenia, co rozumie się przez skutek w prawie karnym; szerzej zob. na przykład J. Śliwowski, Prawo karne, Warszawa 1979, s. 102-108; W. Wróbel, A. Zoll, Polskie prawo karne. Część ogólna, Kraków 2010, s. 192.

25 W Stowniku języka polskiego Państwowego Wydawnictwa Naukowego wskazano, że „dawać fałszywe świadectwo" znaczy tyle, co kłamać (sjp.pwn.pl; dostęp: 10.09.2020), kłamstwo zaś to twierdzenie niezgodne z rzeczywistością, mające wprowadzić kogoś w błąd (sjp.pwn.pl; dostęp: 10.09.2020).

${ }^{26}$ W słowniku języka polskiego przy słowie „fałszywy” wskazano, że znaczy tyle, co nieprawdziwy, oszukańczy, podrobiony; sjp.pl (dostęp: 10.09.2020).

27 Trzeba jednak odnotować, że w odniesieniu do przestępstwa fałszywego oskarżenia w orzecznictwie również przyjęto możliwość dokonania tegoż w zamiarze ewentualnym; zob. uchwałę Sądu Najwyższego z 17 maja 2011 roku, SNO 6/11, Lex nr 1288955. Zob. też wyrok Sądu Apelacyjnego w Szczecinie z 12 października 2017 roku, II AKa 128/17, Lex nr 2412812.

28 Możliwość popełnienia przestępstwa $\mathrm{z}$ art. $233 \S 6 \mathrm{k} . \mathrm{k}$. jedynie w formie zamiaru bezpośredniego przyjął L. Tyszkiewicz, [w:] Kodeks karny. Komentarz, red. M. Filar, Warszawa 2008, s. 940. Inaczej, dopuszczając możliwość popełnienia tego przestępstwa w formie zamiaru bezpośredniego lub ewentualnego, zob. między innymi B. Kunicka-Michalska, op. cit., komentarz do art. 233, 
Patrząc z perspektywy tematu tego opracowania, należy przyjąć, że może je popełnić zarówno ten komornik sądowy, który składając oświadczenie majątkowe ma świadomość, że zawarte w nim informacje są nieprawdziwe, a mimo to składa właściwemu prezesowi sądu oświadczenie (zamiar bezpośredni), jak i ten komornik sądowy, który przewidując z dużym prawdopodobieństwem, że zawarte w oświadczeniu majątkowym informacje są nieprawdziwe, składa je właściwemu prezesowi sądu, godząc się na złożenie fałszywego oświadczenia majątkowego (zamiar ewentualny) ${ }^{29}$. Minimalnym warunkiem spełnienia znamion strony podmiotowej $\mathrm{w}$ odniesieniu do przestępstwa polegającego na złożeniu fałszywego oświadczenia majątkowego jest zatem przewidywanie przez komornika sądowego, że wysoce prawdopodobne jest, że przynajmniej jedna spośród wymaganych od niego i zawartych w składanym oświadczeniu informacji o stanie majątku jest nieprawdziwa, a zarazem godzenie się z tym stanem rzeczy wyrażające się przede wszystkim w złożeniu danego oświadczenia prezesowi właściwego sądu ${ }^{30}$.

Zakresem czynu wyczerpującego znamiona przestępstwa złożenia fałszywego oświadczenia można objąć tylko tę jego część, do której odnoszą się udowodnione znamiona strony podmiotowej ${ }^{31}$. Przypisując oskarżonemu popełnienie danego przestępstwa, sąd ma obowiązek nie tylko na podstawie konkretnych dowodów, w drodze logicznego rozumowania, wykazać, że ustawowe znamiona strony podmiotowej zostały zrealizowane, ale nadto określić, czy przypisuje oskarżonemu popełnienie czynu zabronionego z zamiarem bezpośrednim czy ewentualnym ${ }^{32}$.

Umyślność zachowania jako warunek odpowiedzialności za przestępstwo nie może być wywodzona z samego faktu zaistnienia znamion strony przedmiotowej danego czynu zabronionego, na przykład stąd, że w danym oświadczeniu majątkowym zawarto informacje niezgodne $\mathrm{z}$ prawdą ${ }^{33}$. Ustawowe znamiona strony podmiotowej czynu zabronionego podlegają udowodnieniu zasadniczo tak samo, jak znamiona strony przedmiotowej. Jedynie wyjątkowo umyślność można in concreto wywodzić na podstawie samych tylko okoliczności towarzyszących popełnieniu przestępstwa, takich jak na przykład udział w zorganizowanej grupie przestępczej, w ramach której zatajano dochody i źródła dochodów uczestników tej grupy, firmowanie działalności danej osoby przez inną, przyjmowanie niedozwolonych korzyści majątkowych, pozyskiwanie zatajanych dochodów lub okre-

nb V. 1; oraz I. Zgoliński, [w:] Kodeks karny. Komentarz, red. V. Konarska-Wrzosek, Warszawa 2020, komentarz do art. 233, nb 5; M. Szewczyk, A. Wojtaszczyk, W. Zontek, [w:] Kodeks karny. Część szczególna, t. 2, cz. 2. Komentarz do art. 212-277d, red. A. Zoll, W. Wróbel, Warszawa 2017, komentarz do art. 233, nb 37; J. Piórkowska-Flieger, [w:] Kodeks karny. Komentarz, red. T. Bojarski, Warszawa 2016, komentarz do art. 233, nb 5.

29 Podobnie M. Sławiński, Znamiona ..., s. 51.

30 Por. wyrok Sądu Najwyższego z 15 stycznia 1999 roku, II KKN 129/97, Legalis.

31 Ibidem.

32 Wyrok Sądu Apelacyjnego we Wrocławiu z dnia 4 września 2013 roku, II AKa 246/13, Legalis.

33 Zob. na przykład wyrok Sądu Najwyższego z 30 maja 2001 roku, II KKN 85/99, Legalis. 
ślonych aktywów itp. W innych przypadkach ustalenie zamiaru złożenia przez komornika sądowego fałszywego oświadczenia majątkowego wymaga przedstawienia wiarygodnych dowodów świadczących o jego umyślnym działaniu.

Warto zaakcentować, że chodzi tu o wykazanie umyślności działania sprawcy tempore criminis. Ustalanie, że komornik sądowy zorientował się, że jego oświadczenie majątkowe zawiera nieprawdziwe dane lub nie zawiera wymaganych danych o stanie jego majątku dopiero po złożeniu oświadczenia majątkowego, nie świadczy przecież o tym, że zamierzał złożyć fałszywe oświadczenie. Więcej nawet, zachowania komornika sądowego mające miejsce już po złożeniu danego oświadczenia, a zmierzające do jego poprawienia lub ujawniające w inny sposób rzeczywisty stan majątku, w szczególności dobrowolne złożenie korekty oświadczenia majątkowego - niewymaganej wszakże przepisami ustawy o komornikach sądowych — przekonują raczej o nieumyślnym złożeniu oświadczenia majątkowego, którego treść okazała się nieprawdziwa.

W orzecznictwie słusznie podkreśla się, że dla oceny nastawienia psychicznego sprawcy do popełnianego czynu polegającego na złożeniu nieprawdziwego oświadczenia majątkowego niebagatelne znaczenie ma ponadto ustalenie przyczyn złożenia nieprawdziwego oświadczenia będącego przedmiotem danego postępowania karnego. W każdym razie samo tylko ustalenie okoliczności dotyczących pełnienia określonej funkcji publicznej, obligujących do złożenia oświadczenia oraz faktu złożenia oświadczenia majątkowego niezgodnego z prawdą, jest niewystarczające dla stwierdzenia popełnienia przestępstwa $\mathrm{z}$ art. $233 \S 6$ k.k. ${ }^{34}$

Oceniając zachowanie komornika sądowego, który złożył nieprawdziwe oświadczenie majątkowe, nie można też abstrahować od nie dość skonkretyzowanego wzoru formularza oświadczenia majątkowego. Wskazuje się, że nie tylko zdaniem komorników sądowych, którzy przecież nie są i nie powinni być specjalistami od wypełniania tego typu formularzy, ale także w ocenie wyspecjalizowanych służb państwowych, w szczególności Centralnego Biura Antykorupcyjnego, treść formularza rodzi zbyt wiele wątpliwości ${ }^{35}$. W komentarzach proponuje się niekiedy, aby w związku z tym wypełniać oświadczenie majątkowe na zasadzie

34 Por. postanowienie Sądu Najwyższego z 13 maja 2013 roku, II KK 274/09, Legalis; wyrok Sądu Okręgowego w Gliwicach z 15 marca 2016 roku, IV Ka 1195/15, orzeczenia.ms.gov. pl (dostęp: 15.11.2020); wyrok Sądu Okręgowego w Gliwicach z 5 listopada 2015 roku, IV Ka 136/15, www.saos.org.pl (dostęp: 15.11.2020); wyrok Sądu Rejonowego w Białymstoku z 18 października 2013 roku, III K 376/13, orzeczenia.bialystok.sr.gov.pl (dostęp: 15.11.2020). Szerzej zob. Z. Doda, A. Gaberle, Dowody w procesie karnym. Orzecznictwo Sądu Najwyższego. Komentarz, t. 1, Warszawa 1997, s. 50-51 i cytowane tam przez autorów orzeczenia Sądu Najwyższego.

${ }^{35}$ Centralne Biuro Antykorupcyjne, op. cit., s. 76-77. Zob. też S. Kowalski, op. cit., s. 84-86; M. Świtkowski, [w:] Komentarz do ustawy o komornikach sądowych, red. M. Świtkowski, M. Simbierowicz, Warszawa 2019, komentarz do art. 32, nb 10; oraz ostatnią część uzasadnienia do wyroku Sądu Rejonowego w Białymstoku z 18 października 2013 roku, III K 376/13, orzeczenia. bialystok.sr.gov.pl (dostęp: 15.11.2020). 
„lepiej więcej, niż mniej”36, nie wydaje się jednak, żeby była to dobra rada. Abstrahując od tego, że przecież chodzi tu o dokument (wzór formularza), którego wypełnienie w sposób nierzetelny może skutkować ponoszeniem odpowiedzialności karnej, zauważyć wypada, że pominięcie istotnego, wymaganego składnika majątku w oświadczeniu, w którym napisano nader wiele (zbyt wiele) o innych składnikach majątku, może in concreto przywieść na myśl skojarzenie, że to właśnie jest argumentem za świadomym zatajeniem danych o majątku. Niezależnie od tego, zawarcie we wzorze formularza części żądającej ujawnienia ,innych dodatkowych danych o stanie majątku", prowadzi do wniosku o niekonstytucyjności tego rozwiązania, gdyż w świetle treści art. 32 ust. 2 i 12 u.k.s. uzasadnione jest twierdzenie, że Minister Sprawiedliwości nie miał upoważnienia ustawowego do zawarcia w formularzu danych objętych jego częścią IX ${ }^{37}$. Oświadczenia majątkowe komorników sądowych są jawne i znacząco wątpliwe jest „nadmiernie obfite” ich wypełnianie, chociażby z uwagi na bezpieczeństwo komorników sądowych i osób im najbliższych ${ }^{38}$.

Należy podkreślić, że w sprawach dotyczących złożenia fałszywego oświadczenia majątkowego sądy nie raz odnosiły się krytycznie do stawianych przez prokuratora zarzutów, wskazując, że oskarżyciel publiczny nie przedstawił wiarygodnych dowodów świadczących o umyślnym zachowaniu sprawcy. Przykładowo w sprawie zakończonej wyrokiem uniewinniającym wydanym przez Sąd Rejonowy w Białymstoku 18 października 2013 roku $^{39}$ sąd podkreślit, że nie może być uznane za umyślne nieujawnienie udziału (trzeciej części) w prawie własności samochodu wartego $12000 \mathrm{zł} \mathrm{w}$ oświadczeniu majątkowym złożonym przez zastępcę burmistrza jednego $\mathrm{z}$ miast, skoro $\mathrm{z}$ jednej strony prawidłowe wypełnienie formularza oświadczenia majątkowego wymaga określonej prawniczej wiedzy, z drugiej zaś - oskarżony nie taił faktu posiadania danego samochodu (poruszał się nim). Tym bardziej, że po zweryfikowaniu błędnego przekonania, że tego typu składnik majątku nie powinien być ujawniony w oświadczeniu majątkowym, dobrowolnie ujawnił go w toku czynności kontrolujących prawdziwość oświadczenia. Warto dodać, że w tej samej sprawie zastępcy burmistrza zarzucono także nieujawnienie w oświadczeniu majątkowym pożyczek udzielonych mu przez brata na zakup lokalu mieszkalnego w łącznej kwocie 20 643,19 zł. Sąd — stwierdziwszy, że chodziło o pożyczki na zakup nieruchomości przeniesionej później na brata oskarżonego, który pożyczek udzielał, a który był mniej od niego majętny i nie miał zdolności

36 M. Świtkowski, op. cit., komentarz do art. 32, nb 10.

37 S. Kowalski, op. cit., s. 65-73.

38 Art. 32 ust. 7 i 9 u.k.s. Zaniechanie ujawniania danych adresowych, informacji o miejscu położenia nieruchomości, a także informacji umożliwiających identyfikację ruchomości komornika nie czyni bynajmniej trudnymi do ustalenia tych danych przez zorganizowane grupy trudniące się kradzieżami czy innymi przestępstwami mającymi na celu szybkie uzyskanie korzyści majątkowych.

39 III K 376/13, http://orzeczenia.bialystok.sr.gov.pl/details/\$N/150505050001506_III_K_ 000376_2013_Uz_2014-01-27_001 (dostęp: 15.11.2020). 
kredytowej pozwalającej zaciągnąć kredyt na zakup lokalu mieszkalnego — uznał, że nie sposób przypisać oskarżonemu zamiaru złożenia fałszywego oświadczenia majątkowego. Oskarżony nabył wprawdzie na swój rachunek daną nieruchomość (w tym za pieniądze przekazane przez brata), ale po to, żeby później przenieść na brata własność tej nieruchomości. Przekazane przez brata środki nie wpłynęły zatem (i nie miały wpłynąć) na zwiększenie aktywów oskarżonego, a więc — zdaniem sądu - nie można było mówić o umyślnym zatajeniu zobowiązań majątkowych podlegających ujawnieniu w oświadczeniu majątkowym ${ }^{40}$.

W orzecznictwie sądów rejonowych i okręgowych jako okoliczności świadczące o braku zamiaru w złożeniu fałszywego oświadczenia majątkowego wskazywano między innymi: 1 . brak celu zatajenia danego składnika majątku ${ }^{41}$; 2. ujawnienie danego składnika majątku nieujawnionego w jednym z oświadczeń w innym (kolejnym) oświadczeniu pozwalającym na łatwą weryfikację stanu majątku oskarżonego ${ }^{42} ; 3$. nietajenie posiadania określonego składnika majątku (nieujętego w oświadczeniu) umożliwiające łatwą weryfikację stanu majątku danej osoby ${ }^{43}$; 4 . zapomnienie ujawnienia danego składnika majątku ${ }^{44}$. W odniesieniu do kwestii zapomnienia jako okoliczności prowadzącej do przyjęcia, że dane zachowanie sprawcy jest na przykład nieumyślne ${ }^{45}$, godzi się jednak zauważyć, że oświadczenie majątkowe jest składane na określonym formularzu przez funkcjonariusza publicznego, na którego nakładane są szczególne w tej mierze obo-

40 Ibidem. Sąd zakwestionował w tym zakresie również sam obowiązek ujawnienia takich pożyczek w składanym oświadczeniu majątkowym.

41 Zob. wyrok Sądu Okręgowego w Gliwicach z 5 listopada 2015 roku, IV Ka 136/15, http:// orzeczenia.gliwice.so.gov.pl/content/\$N/151515001012506_V_Ka_000136_2015_Uz_2015-11-05 001 (dostęp: 15.11.2020), a także niepublikowane wyroki sądów, od których wywiedziono kasację rozpoznawaną przez Sąd Najwyższy w dniu 13 maja 2010 roku, II KK 274/09, Legalis.

42 Zob. wyrok Sądu Okręgowego w Gliwicach z 5 listopada 2015 roku, IV Ka 136/15, http://orze czenia.gliwice.so.gov.pl/content/\$N/151515001012506_V_Ka 000136_2015_Uz 2015-11-05_001 (dostęp: 15.11.2020).

43 Zob. wyrok Sądu Rejonowego w Białymstoku z 18 października 2013 roku, III K 376/13, http://orzeczenia.bialystok.sr.gov.pl/details/\$N/150505050001506_III_K_000376_2013_Uz_201401-27_001 (dostęp: 15.11.2020); warto jednak zauważyć, że kwestia ta okazała się nie mieć aż tak istotnego znaczenia dla sądu pierwszej instancji w głośnej sprawie byłego ministra Sądu Najwyższego, który posiadał drogi zegarek nieujawniony w oświadczeniu majątkowym z czym nie krył się i co ujawnił dziennikarz, a nie służby państwowe odpowiadające za weryfikację oświadczeń majątkowych; zob. wyrok Sądu Rejonowego dla Warszawy-Śródmieścia w Warszawie z 27 listopada 2014 roku, II K 119/14, http://orzeczenia.srodmiescie.warszawa.so.gov.pl/details/ \$N/154505300001006_II_K_000119_2014_Uz_2015-01-19_001 (dostęp: 15.11.2020).

44 Wyrok Sądu Rejonowego w Białymstoku z 18 października 2013 roku, III K 376/13, http:// orzeczenia.bialystok.sr.gov.pl/details/\$N/150505050001506_III_K_000376_2013_Uz_2014-0127_001 (dostęp: 15.11.2020).

45 Zob. zwłaszcza M. Król-Bogomilska, Odpowiedzialność karna za przestęstwa popetnione wskutek zapomnienia, „Zeszyty Naukowe Instytutu Badań Prawa Sądowego” 1979, nr 12, s. 62-78; W. Wolter, Oceny prawnokarne zapomnienia, „Państwo i Prawo” 1985, z. 5, s. 43-44; A. Chmiel, Kilka uwag o tzw. przestępstwach z zapomnienia, „Palestra” 1991, nr 3-4, s. 10-12. 
wiązki ujawnienia informacji wymagających odtwarzania konkretnych danych z pamięci, w tym posłużenia się odpowiednimi dokumentami w czasie spisywania treści oświadczenia. Dla przyjęcia zatem, że oskarżony rzeczywiście nie pamiętał o potrzebie wpisania określonych informacji w formularzu oświadczenia majątkowego, skutkiem czego należałoby jego zachowanie oceniać jako nieumyślne ${ }^{46}$, konieczne jest dokonanie na podstawie zebranych dowodów ustaleń na tę okoliczność, pozwalających usprawiedliwić zaniechanie oskarżonego ${ }^{47}$. W konkretnym przypadku zapomnienie może usprawiedliwiać na przykłąd niedokładne określenie wymaganych danych w formularzu oświadczenia majątkowego albo dysponowanie przez składającego oświadczenie tak dużym majątkiem, że faktycznie może nie pamiętać o jego niewielkiej, nieujawnionej części. Żadne z wyżej wymienionych ustaleń na okoliczność strony podmiotowej nie powoduje per se, że niemożliwe jest przypisanie oskarżonemu zamiaru złożenia fałszywego oświadczenia majątkowego. Ujawnienie którejkolwiek z nich powoduje natomiast konieczność pogłębionej in concreto refleksji nad oceną dowodów zgromadzonych $\mathrm{w}$ danej sprawie na okoliczność wyczerpania przez oskarżonego ustawowego znamienia strony podmiotowej czynu z art. $233 \S 6$ k.k. Ażeby w konkretnej sprawie przypisać oskarżonemu zamiar złożenia fałszywego oświadczenia majątkowego, wnioski w tym zakresie muszą być prawidłowe pod względem logicznym i jednocześnie wykluczać odmienne, również logiczne, dowodzenie ${ }^{48}$. Zarazem podstawę wyroku - zwłaszcza w zakresie ustaleń dotyczących strony podmiotowej czynu - może stanowić jedynie całokształt okoliczności ujawnionych w toku rozprawy głównej, zaś ustalenia faktyczne nie mogą wykazywać błędów natury logicznej i być zgodne z zasadami doświadczenia życiowego i wskazaniami wiedzy ${ }^{49}$.

\section{USTAWOWE GRANICE KARY ZA PRZESTĘPSTWO ZŁOŻENIA FAŁSZYWEGO OŚWIADCZENIA}

Przestępstwo złożenia fałszywego oświadczenia, stypizowane w art. $233 \S 6$ k.k., jest zagrożone bardzo surową sankcją karną — od sześciu miesięcy do ośmiu lat pozbawienia wolności. Ustawodawca nie przewiduje w odniesieniu do tego czynu wypadku mniejszej wagi. Prima vista należy więc zauważyć, że przypisanie tego przestępstwa uniemożliwia zastosowanie względem sprawcy warunkowego umorzenia postępowania karnego, nawet jeśli stopień społecznej szkodliwości danego czynu i stopień winy są nieznaczne. Warunkowe umorzenie postępowania karnego

46 W. Wolter, op. cit., s. 43-44; A. Chmiel, op. cit., s. 11-12.

47 Por. M. Sławiński, Znamiona..., s. 53 i uwagi zawarte przez tego autora w przypisie nr 42.

48 Por. M. Laskowski, Ustalanie umyślności w praktyce orzeczniczej, [w:] Ustalanie umyślności w praktyce orzeczniczej, red. J. Majewski, Toruń 2011, s. 63; wyrok Sądu Apelacyjnego w Katowicach z 7 lipca 2005 roku, II AKa 13/05, Legalis.

49 Z. Doda, A. Gaberle, op. cit., s. 284-288; zob. cytowane przez autorów orzeczenia. 
jest bowiem możliwe jedynie w odniesieniu do sprawcy przestępstwa zagrożonego karą nieprzekraczającą pięciu lat pozbawienia wolności (art. 66 § 2 k.k.).

Do chwili wejścia w życie art. $233 \S 6$ k.k. przestępstwo w nim stypizowane było zagrożone znacznie bardziej przemyślaną sankcją — karą do trzech lat pozbawienia wolności. Uregulowanie to radykalnie zmieniło się $\mathrm{z}$ chwilą wejścia w życie ustawy z dnia 11 marca 2016 roku o zmianie ustawy - Kodeks postępowania karnego oraz niektórych innych ustaw ${ }^{50}$. Wymienioną ustawą podwyższono znacznie ustawowe granice kary za przestępstwo z art. 233 § 1 k.k., zaś z uwagi na brzmienie art. $233 \S 6$ k.k., który nie określa samodzielnie ustawowych granic kary, lecz odsyła właśnie do art. $233 \S 1$ k.k., zarazem za przestępstwo złożenia fałszywego oświadczenia. W uzasadnieniu projektu ustawy z 11 marca 2016 roku kwestię podwyższenia ustawowych granic kary za przestępstwo z art. $233 \S 6$ k.k. całkowicie pominięto, tak jakby nie dostrzegano skutków planowanego zabiegu legislacyjnego dotyczącego art. $233 \S 1$ k.k. in fine ${ }^{51}$. Tymczasem reperkusje tej zmiany są bardzo poważne zwłaszcza dla funkcjonariuszy publicznych, którzy składając fałszywe oświadczenie majątkowe, realizują znamiona czynu zabronionego $\mathrm{z}$ art. $233 \S 6 \mathrm{k} . \mathrm{k}$.

Zgoła inaczej przedstawia się natomiast zagrożenie karą za przestępstwo związane ze złożeniem nieprawdziwego oświadczenia majątkowego przez osoby pełniące najwyższe urzędy państwowe ${ }^{52}$ oraz funkcjonariuszy Straży Granicznej. W przypadku przestępstw stypizowanych $\mathrm{w}$ art. 14 ust. 1 ustawy antykorupcyjnej oraz art. $147 \mathrm{~b}$ ust. 1 u.s.g. ustawodawca przewiduje - nawet $\mathrm{w}$ typie podstawowym przestępstwa związanego ze złożeniem nieprawdziwego oświadczenia majątkowego - górną granicę ustawowego zagrożenia karą na pułapie pięciu lat pozbawienia wolności, a więc umożliwiającą zastosowanie instytucji warunkowego umorzenia postępowania karnego, która gwarantuje niekaralność sprawcy tego czynu zabronionego. Co więcej, w każdym z wymienionych artykułów ustawodawca przewiduje kolejny ustęp, w którym typizuje wypadek mniejszej wagi zagrożony alternatywnie karami grzywny, ograniczenia wolności albo po-

50 Dz.U. z 2016 r. poz. 437; ustawa ta weszła w życie 15 kwietnia 2016 roku. Warto zwrócić uwagę, że przed wejściem w życie sprawy dotyczące złożenia fałszywego oświadczenia majątkowego wcale nierzadko kończyły się warunkowym umorzeniem postępowania karnego, zob. na przykład wyrok Sądu Okręgowego w Sieradzu z 1 października 2014 roku, II Ka 223/14, niepublikowany; wyrok Sądu Okręgowego w Łomży, II Ka 253/13, http:/orzeczenia.lomza.so.gov.pl/ content/\$N/150510000001006_II_Ka_000253_2013_Uz_2013-11-27_002 (dostęp: 15.11.2020). Tak też zakończyła się sprawa byłego ministra, w której przypisano mu złożenie nieprawdziwych oświadczeń majątkowych nieobejmujących informacji o posiadanym zegarku wartości przeszło 10 tysięcy zł. (zob. Są uchylit wyrok w sprawie zegarka Stawomira Nowaka, 27.05.2015, https:// wiadomosci.dziennik.pl/polityka/artykuly/491495,sad-uchylil-wyrok-w-sprawie-zegarka-slawo mira-nowaka.html (dostęp: 15.11.2020).

51 Uzasadnienie Rządowy projekt ustawy o zmianie ustawy - Kodeks postępowania karnego oraz niektórych innych ustaw, druk nr 207 Sejmu RP VIII kadencji, s. 19-21 uzasadnienia.

$52 \mathrm{Na}$ temat zakresu podmiotowego obowiązku złożenia oświadczenia majątkowego na podstawie przepisów ustawy antykorupcyjnej zob. zwłaszcza D. Gruszecka et al., op. cit., s. 716-718. 
zbawienia wolności do roku. Trzeba skonstatować, że z perspektywy celu, jakiemu ma służyć kryminalizowanie zachowań polegających na zatajaniu prawdy lub podawaniu nieprawdy w oświadczeniach majątkowych, sposób typizacji i ustawowe granice kary przewidziane w przepisach art. 14 ustawy antykorupcyjnej oraz art. 147b u.s.g. są znacznie bardziej racjonalnie określone niż w art. $233 \S 1$ i § 6 k.k. Obowiązek składania rzetelnych oświadczeń majątkowych ma służyć jedynie przeciwdziałaniu korupcji, przenikaniu się władztwa publicznego i gospodarki tudzież naruszeniom zasad etyki. Intencją ustawodawcy przy tworzeniu przepisów antykorupcyjnych jest bowiem możliwość weryfikacji, czy zachodzi związek przyczynowy między faktem pełnienia określonej funkcji, z którą wiąże się obowiązek złożenia oświadczenia, a zmieniającym się stanem majątkowym osoby składającej to oświadczenie ${ }^{53}$.

Ustawowe granice kary przewidziane za przestępstwo z art. $233 \S 6$ k.k. uniemożliwiają odstąpienie od wymierzenia kary na podstawie art. 59 k.k. Ustawodawca przewiduje wprawdzie możliwość odpowiedniego ${ }^{54}$ zastosowania odnośnie do osoby składającej fałszywe oświadczenie regulacji przewidzianej w art. $233 \S 5$ k.k., w którym ustala się szczególne podstawy nadzwyczajnego złagodzenia kary lub odstąpienia od jej wymierzenia, ale niezmiernie trudno wyobrazić sobie stosowanie przepisów art. $233 \S 5$ k.k. do oświadczeń majątkowych składanych pod rygorem odpowiedzialności karnej. Degresja karania przewidziana w przepisach art. $233 \S 5$ k.k. jest wszakże uzależniona od określonego wpływu, jaki fałszywe zeznanie lub sprostowanie tegoż (i innych wskazanych w tych przepisach wypowiedzi) wywiera na „rozstrzygnięcie sprawy" ${ }^{55}$, tymczasem jednak złożenie oświadczenia majątkowego nie następuje w żadnym spośród postępowań prowadzonych na podstawie ustawy, nie może więc mieć wpływu na ich wynik.

\section{KONKLUZJE}

1. Za złożenie fałszywego oświadczenia majątkowego komornik sądowy może ponosić odpowiedzialność karną — za przestępstwo stypizowane w art. 233 $\S 6$ k.k. Jest to przestępstwo umyślne, ścigane z oskarżenia publicznego, a więc postawienie zarzutu jego popełnienia wiąże się z zawieszeniem komornika sądowego w czynnościach (art. 18 ust. 1 pkt 2 u.k.s.), zaś skazanie za to przestępstwo skutkuje wygaśnięciem powołania na stanowisko komornika z mocy prawa (art. 20 ust. 1 pkt 4 u.k.s.).

53 Wyrok Sądu Rejonowego w Białymstoku z 18 października 2013 roku, III K 376/13, http:// orzeczenia.bialystok.sr.gov.pl/details/\$N/150505050001506_III_K_000376_2013_Uz_2014-0127_001 (dostęp: 15.11.2020).

54 Zob. J. Nowacki, „Odpowiednie” stosowanie przepisów prawa, „Państwo i Prawo” 1964, z. 3, passim.

55 Wiąże się to z tym, że zeznania, opinie, ekspertyzy lub thumaczenia, o których mowa w przepisach art. $233 \S 1-4$ k.k., składane są w określonym postępowaniu. 
2. Fałszywe oświadczenie majątkowe to oświadczenie, w którym zawarte są informacje niezgodne z prawdą, a więc nie zawiera ono wszystkich danych, które powinny w tym oświadczeniu się znaleźć lub zawarte w nim dane są niezgodne z prawdą. Nie jest fałszywym oświadczenie nieprawidłowo wypełnione, w oparciu o które można ustalić wszystkie podlegające ujawnieniu składniki majątku.

3. W doktrynie przyjmuje się, że przestępstwo polegające na złożeniu fałszywego oświadczenia majątkowego może być popełnione tylko w zamiarze bezpośrednim lub ewentualnym. W takim razie należałoby przyjąć, że minimalnym warunkiem spełnienia znamion strony podmiotowej w odniesieniu do przestępstwa polegającego na złożeniu fałszywego oświadczenia majątkowego przez komornika sądowego jest przewidywanie, że wysoce prawdopodobne jest, iż chociażby jedna informacja o stanie majątku wymagana od niego, zawarta w składanym oświadczeniu, jest nieprawdziwa (albo nie została podana, mimo że jest wymagana), a zarazem godzenie się $\mathrm{z}$ tym stanem rzeczy, wyrażające się w złożeniu danego oświadczenia prezesowi właściwego sądu.

4. Zarówno znamiona strony przedmiotowej, jak i znamiona strony podmiotowej podlegają w procesie karnym udowodnieniu. Ciężar dowodu spoczywa na oskarżycielu publicznym.

5. Odpowiedzialność karna komornika sądowego i innych funkcjonariuszy państwowych, którzy składają oświadczenie majątkowe pod rygorem odpowiedzialności karnej za przestępstwo z art. $233 \S 6$ k.k., jest znacznie surowsza niż odpowiedzialność karna za złożenie oświadczenia majątkowego najwyższych rangą funkcjonariuszy państwowych, na przykład premiera, ministrów czy wiceministrów. Ustawowe granice kary przewidziane przez ustawodawcę za przestępstwo z art. $233 \S 6$ k.k. uniemożliwiają zastosowanie in concreto warunkowego umorzenia postępowania karnego, ustawodawca nie przewiduje również wypadku mniejszej wagi czynu stypizowanego w ostatnio wskazanym artykule. To rozwiązanie legislacyjne jest nieakceptowalne, gdyż tak represyjne skutki złożenia przez komornika sądowego fałszywego oświadczenia majątkowego nie mają racjonalnego uzasadnienia.

6. Jeżeli w ocenie ustawodawcy istotnie konieczne jest utrzymywanie rygoru odpowiedzialności karnej za złożenie fałszywego oświadczenia majątkowego przez komornika sądowego i innych funkcjonariuszy publicznych, to należałoby stypizować taki czyn w kodeksie karnym w rozdziale XXIX, gdzie pomieszczone są przestępstwa przeciwko działalności instytucji państwowych oraz samorządu terytorialnego. Wówczas rodzajowy przedmiot ochrony przestępstw stypizowanych w tym rozdziale byłby spójny z bezpośrednim przedmiotem ochrony przestępstwa polegającego na złożeniu fałszywego oświadczenia majątkowego, a co ważniejsze - ustawodawca przewidywałby jednolitą odpowiedzialność karną za złożenie takiego oświadczenia dla wszystkich do tego zobowiązanych funkcjonariuszy publicznych. 


\title{
CRIMINAL LIABILITY OF A COURT ENFORCEMENT OFFICER FOR SUBMITTING A FALSE ASSETS DECLARATION
}

\author{
Summary
}

The aim of the study is to present the issue of criminal liability of a court enforcement officer for submitting a false assets declaration. The author discusses both, the statutory features of a prohibited act under Article $233 \S 6$ of the Penal Code from the perspective of submitting assets declaration that is false in its content, and criminal law consequences of the aforementioned crime. In the author's opinion, the current legislative solutions are excessively repressive. In particular, sanctions for submitting a false assets declaration by a court enforcement officer go further than the consequences of submitting a false assets declaration by the prime minister, minister or deputy minister. De lege ferenda, the author proposes the unification of criminal liability of public officials for providing false data in assets declaration.

Keywords: crime, penalty, false assets declaration, court enforcement officer

\section{BIBLIOGRAFIA:}

Centralne Biuro Antykorupcyjne, Oświadczenia majątkowe (wydanie uzupetnione), „Przegląd Antykorupcyjny" 2019, nr 1.

Chmiel A., Kilka uwag o tzw. przestępstwach z zapomnienia, „Palestra” 1991, nr 3-4.

Doda Z., Gaberle A., Dowody w procesie karnym. Orzecznictwo Sądu Najwyższego. Komentarz, t. 1, Warszawa 1997.

Górniok O., [w:] Kodeks karny. Komentarz, t. 3. Art. 117-363, red. O. Górniok, S. Hoc, S.M. Przyjemski, Gdańsk 1999.

Gruszecka D., Jasiński W., Kremens K., Skorupka J., Działalność gospodarcza, ograniczenie dla osób petniących funkcje publiczne. Art.14, [w:] System prawa karnego, t. 11. Szczególne dziedziny prawa karnego. Prawo wojskowe, skarbowe i pozakodeksowe, red. M. Bojarski, Warszawa 2018.

Jachimowicz M., Odpowiedzialność karna za naruszenie przepisów ustawy „antykorupcyjnej”, „Prokuratura i Prawo” 2006, nr 10.

Kallaus Z., Przestępstwa przeciwko wiarygodności dokumentów, „Nowa kodyfikacja karna. Kodeks karny. Krótkie komentarze" 1998, z. 7.

Kowalski S., Oświadczenie majątkowe komornika sądowego — zagadnienie właściwego określenia wzoru formularza, „Przegląd Prawa Egzekucyjnego” 2020, nr 8.

Król-Bogomilska M., Odpowiedzialność karna za przestępstwa popetnione wskutek zapomnienia, „Zeszyty Naukowe Instytutu Badań Prawa Sądowego” 1979, nr 12.

Kulik M., Czy bezpodstawne uchylenie się od złożenia zeznania jest zatajeniem prawdy w rozumieniu art. 233 \& 1 k.k.?, „Wojskowy Przegląd Prawniczy” 2003, nr 3.

Kunicka-Michalska B., [w:] Kodeks karny. Komentarz, red. A. Wąsek, Warszawa 2010.

Laskowski M., Ustalanie umyślności w praktyce orzeczniczej, [w:] Ustalanie umyślności w praktyce orzeczniczej, red. J. Majewski, Torun 2011.

Młynarczyk Z., Fatszywe zeznania w polskim prawie karnym, Warszawa 1971.

Nowacki J., ,,Odpowiednie” stosowanie przepisów prawa, „Państwo i Prawo” 1964, z. 3.

Piórkowska-Flieger J., [w:] Kodeks karny. Komentarz, red. T. Bojarski, Warszawa 2016.

Reiwer R., Ustawa o komornikach sądowych. Komentarz, Warszawa 2019. 
Sławiński M., Penalizacja złożenia fatszywego oświadczenia majątkowego przez osobe petniąca funkcje publiczną. Wybrane aspekty dotyczące bezprawności, systematyki przepisów oraz dobra prawnie chronionego, „Czasopismo Prawa Karnego i Nauk Penalnych” 2015, z. 1.

Sławiński M., Znamiona przedmiotowe i podmiotowe przepisów penalizujących złożenie fatszywego oświadczenia majątkowego przez osobę petniaca funkcję publiczna (wykładnia art. $233 \S 6$ k.k. $w z w . z$ art. 233 \& 1 k.k. oraz art. 14 ustawy antykorupcyjnej), „Czasopismo Prawa Karnego i Nauk Penalnych" 2015, z. 4.

Szewczyk M., Wojtaszczyk A., Zontek W., [w:] Kodeks karny. Część szczególna, t. 2, cz. 2. Komentarz do art. 212-277d, red. A. Zoll, W. Wróbel, Warszawa 2017.

Śliwowski J., Prawo karne, Warszawa 1979.

Świtkowski M., [w:], Komentarz do ustawy o komornikach sądowych, red. M. Świtkowski, M. Simbierowicz, Warszawa 2019.

Tyszkiewicz L., [w:] Kodeks karny. Komentarz, red. M. Filar, Warszawa 2008.

Wojtaszczyk A., Wróbel W., Zontek W., Przestępstwa przeciwko wymiarowi sprawiedliwości, [w:] System prawa karnego, t. 8. Przestępstwa przeciwko państwu i dobrom zbiorowym, red. L. Gardocki, Warszawa 2018.

Wolter W., Oceny prawnokarne zapomnienia, „Państwo i Prawo” 1985, z. 5.

Wróbel W., Zoll A., Polskie prawo karne. Część ogólna, Kraków 2010.

Zalewski W., [w:] Kodeks karny. Część szczególna, t. 2. Komentarz do art. 222-316, red. M. Królikowski, R. Zawłocki, Warszawa 2017.

Zgoliński I., [w:] Kodeks karny. Komentarz, red. V. Konarska-Wrzosek, Warszawa 2020. 